
dan Manganese Greensand

\title{
PENURUNAN LOGAM BESI DAN MANGAN MENGGUNAKAN FILTRASI MEDIA ZEOLIT DAN MANGANESE GREENSAND
}

\author{
Nastiti Maharani Oesman ${ }^{1)}$ dan Sugito ${ }^{1)}$ \\ 1) Program Studi Teknik Lingkungan, Fakultas Teknik Sipil dan Perencanaan \\ Universitas PGRI Adi Buana Surabaya \\ Email: nastitimo@gmail.com
}

\begin{abstract}
Abstrak
Didalam bumi, material organik maupun anorganik mengalami berbagai kontak dengan air tanah. Air tanah mengandung beberapa senyawa anorganik seperti logam Besi $(\mathrm{Fe})$ dan Mangan (Mn) yang jika bereaksi dengan udara mengakibatkan perubahan warna pada air tersebut menjadi kuning hingga coklat. Diperlukan teknologi untuk menurunkan kandungan Fe dan Mn tersebut agar layak digunakan sebagai air bersih / air baku. Penelitian ini bertujuan untuk mengkaji Penurunan Fe dan Mn pada air tanah menggunakan filtrasi media Zeolit dan Manganese Greensand. Reaktor filtrasi terbuat dari pipa PVC dengan diameter 4 inchi dan ketinggian $125 \mathrm{~cm}$ serta menggunakan sistem aliran upflow. Variabel dalam penelitian ini adalah jenis media filtrasi yaitu Zeolit dengan Manganese Greensand pada debit $1 \mathrm{~L} /$ menit, 1.5 L/menit, dan 2 L/menit. Sampel yang digunakan adalah air sumur daerah Dukuh Setro Rawasan Surabaya. Analisis Fe menggunakan metode OrthoPhenantrolin secara Spektrofotometri, sedangkan analisis Mn menggunakan metode Persulfat. Setelah ditreatment, untuk media Zeolit efisiensi penurunan paling optimum terjadi pada debit 1 L/menit, dimana untuk Fe sebesar $57.13 \%$ dan Mn sebesar 70.00\%. Sedangkan media Manganese Greensand, efisiensi penurunan paling optimum juga terjadi pada debit $1 \mathrm{~L} / m e n i t$, dimana untuk Fe sebesar $78.36 \%$ dan Mn sebesar $88.21 \%$.
\end{abstract}

Kata Kunci : Fe, Mn, Filtrasi, Zeolit, Manganese Greensand

\begin{abstract}
In the earth, Organic and anorganic material has contact with ground water. Ground water contains some inorganic compounds such as iron and manganese are high causing the color of the water to turn yellow - brown after a while contact with air. The technology needed to reduce the content of $\mathrm{Fe}$ and $\mathrm{Mn}$ in ground water for used to clean water or raw water. This study aims to examine the Efficiency of Iron (Fe) and Manganese (Mn) Decrease on Ground Water Using Manganese Greensand and Zeolite Media Filtration. The filtration reactor is made of 4 inch PVC pipe with a height of $1.25 \mathrm{~m}$ and uses upflow flow system. The variables in this research are combination of filtration media type i.e. zeolite and manganese greensand with flow rate of $1 \mathrm{~L} / \mathrm{min}, 1.5 \mathrm{~L} / \mathrm{min}$, and $2 \mathrm{~L} / \mathrm{min}$. The sample used is the well water in Dukuh Setro Rawasan Surabaya. Fe analysis using Ortho - Phenantrolin method by Spectrophotometry, while Mn analysis using Persulfat method. Fe and Mn content after the treatment has decreased. In zeolite media, the most optimum degradation efficiency occurred at $1 \mathrm{~L} / \mathrm{min}$ discharge, for Fe of $57.13 \%$ and $\mathrm{Mn}$ of $70.00 \%$. While in manganese greensand media, the most optimum degradation efficiency also occurred at $1 \mathrm{~L} / \mathrm{min}$ discharge, for Fe of $78.36 \%$ and $\mathrm{Mn} 88.21 \%$.
\end{abstract}

Keywords : Fe, Mn, Filtration, Zeolite, Manganese Greensand 
Nastiti Maharani Oesman dan Sugito : Penurunan Logam Besi dan Mangan Menggunakan Filtrasi Media Zeolit dan Manganese Greensand

\section{PENDAHULUAN}

Pertumbuhan penduduk yang pesat di Indonesia khususnya di kota-kota besar akan mendorong kebutuhan perumahan serta pemenuhan kebutuhan air bersih. Kualitas air yang bagus merupakan air yang jernih, tidak berwarna, tidak berasa, dan tidak berbau. Tidak semua air dapat digunakan oleh makhluk hidup, terutama manusia. Air yang dapat digunakan untuk kebutuhan manusia harus memenuhi Standar Kualitas Air Bersih yang diatur oleh Departemen Kesehatan berdasarkan Peraturan Menteri Kesehatan Republik Indonesia sesuai Nomor 416/MENKES/PER/IX/1990 dan Standar Kualitas Air Minum yang diatur oleh Departemen Kesehatan berdasarkan Peraturan Menteri Kesehatan Republik Indonesia sesuai Nomor 492/MENKES/PER/IV/2010. Selain kualitas air, yang perlu diperhatikan lagi yaitu kuantitas air. Sumber air bersih bisa didapatkan dari air tanah, air angkasa, dan air permukaan. Air tanah terdiri dari air sumur, air mata air, dan air artesis. Air angkasa yaitu air hujan. Kemudian air permukaan terdiri dari air sungai, danau, waduk, laut, dll. Salah satu sumber air bersih yang dimanfaatkan oleh manusia yaitu air sumur. Berdasarkan uji pendahuluan, diketahui bahwa hasil analisis laboratorium air tanah di daerah Dukuh Setro Rawasan Surabaya menunjukkan nilai Besi (Fe) dan Mangan (Mn) yang cukup tinggi dan melebihi baku mutu yang diperbolehkan, yaitu $1,4 \mathrm{mg} / \mathrm{L}$ untuk Besi dan $1,2 \mathrm{mg} / \mathrm{L}$ untuk Mangan. Sedangkan baku mutu yang diperbolehkan berdasarkan Persyaratan Peraturan Menteri Kesehatan yaitu $1 \mathrm{mg} / \mathrm{L}$ untuk Besi dan 0,5 mg/L untuk Mangan. Berdasarkan fakta lapangan, ciri-ciri air tersebut yaitu berbau logam yang menandakan Mn tinggi, air berwarna kuning kecoklatan, meninggalkan noda kuning-coklat pada baju jika dicuci menggunakan air tersebut, apabila air tersebut digunakan untuk mandi kulit menjadi kering, serta meninggalkan kerak coklat pada bak maupun pipa yang merupakan jalan distribusi air tersebut. Maka dari itu diperlukan teknologi dalam menurunkan kandungan Fe dan Mn pada air tanah.

Permasalahan dalam penelitian ini, yaitu "Adakah perbedaan penurunan kadar Besi (Fe) dan Mangan(Mn) dalam air tanah menggunakan filtrasi media Zeolit dengan Manganese Greensand pada variasi debit 1 L/menit, 1,5 L/menit, dan $2 \mathrm{~L} /$ menit?". Tujuan dalam penelitian ini adalah Untuk mengkaji perbedaan media dalam menurunkan kadar
Besi (Fe) dan Mangan (Mn) dalam air tanah menggunakan filtrasi media Zeolit dan Manganese Greensand. Manfaat dari penelitian ini adalah Sebagai bahan informasi kepada masyarakat tentang penerapan teknologi tepat guna, dalam meningkatkan kualitas air tanah.

Berdasarkan penelitian yang dilakukan oleh Akbar Rhidatul (2014) filter yang terbuat dari pipa PVC dengan volume reaktor 5 L berisi media Zeolit, Pasir Silika, dan Karbon Aktif, dapat menurunkan Fe sebesar 96.17\% pada waktu tinggal 5 menit. Sedangkan penelitian yang dilakukan oleh Anika (2012) tentang Pengaruh Jenis Media Aerated Filter terhadap Penurunan Kadar Besi dan Mangan Pada Air Sumur Gali, hasil penelitian menunjukkan efisiensi penurunan Kadar $\mathrm{Fe}$ sebesar $62.31 \%$ dan Mn sebesar $99.95 \%$ pada debit $15 \mathrm{~mL} /$ menit. Teknologi kombinasi filtrasi memiliki efisiensi penurunan $\mathrm{Fe}$ dan Mn lebih tinggi, seperti kombinasi Filtrasi terpadukan resin (Rahmawati, N. dan Sugito, 2015) menghasilkan efisiensi penurunan lebih dari $90 \%$ untuk Fe dan Mn. Maka dari itu penelitian ini menggunakan media yang sama namun teknologi yang lebih murah yaitu Filtrasi untuk menurunkan Fe dan Mn dengan waktu tinggal yang lebih lama dan bervariasi, diharapkan memiliki efisiensi penurunan yang sama atau bahkan lebih besar dibandingkan penelitian sebelumnya, dengan perkiraan efisiensi lebih dari $70 \%$.

Logam Mangan dan Besi memiliki standar baku mutu yang berbeda sesuai dengan peruntukannya. Pada air minum zat Besi yang terkandung dengan tingkat konsentrasi $\mathrm{mg} / \mathrm{L}$ tidak memberikan pengaruh yang buruk pada kesehatan, tetapi dalam kadar yang besar dapat menyebabkan air menjadi berwarna coklat kemerahan yang tidak diharapkan. Berbeda dengan air permukaan yang memiliki kandungan Besi relatif rendah, air tanah justru memiliki kandungan Besi yang relatif tinggi antara 1-10 $\mathrm{mg} / \mathrm{L}$ (Said, 2005). Hal ini dikarenakan air yang mengalir di dalam tanah melewati celah-celah bebatuan sehingga kandungan kation dan anion batu tersebut larut dalam air. Kontak batuan dengan air tanah relatif luas karena waktu kontak lama dan permeabilitas rendah (Maulana, Fivry W., 2014). Air memiliki kemampuan secara alami untuk pengolahan. Pada suhu dan $\mathrm{pH}$ tertentu dapat mengubah kandungan pada air, terutama $\mathrm{Fe}$ dan Mn. Oleh karena ini di dalam sistem pengolahan air. Logam besi dan Mangan dengan valensi dua lebih larut dalam air, 
Nastiti Maharani Oesman dan Sugito : Penurunan Logam Besi dan Mangan Menggunakan Filtrasi Media Zeolit dan Manganese Greensand

sedangkan valensi tiga lebih sulit larut dalam air. Maka dari itu dilakukan pengolahan dimana logam $\mathrm{Fe}$ dan $\mathrm{Mn}$ diubah menjadi valensi yang lebih tinggi agar mengendap dan bisa dipisahkan dengan mudah, salah satunya dengan filtrasi. Berdasarkan PerMenKes 416/1990 konsentrasi Mangan dalam air bersih maksimal $0.5 \mathrm{mg} / \mathrm{L}$ dan Besi sebesar $1 \mathrm{mg} / \mathrm{L}$. Standar ini ditetapkan karena berdasarkan kenyataan bahwa Besi dan Mangan di dalam air dapat menimbulkan bau dan rasa yang tidak sedap serta air yang berwarna hitam seperti black water (Said, 2005).

Menurut (Purwoto S., 2013) sistem pengolahan air terdiri dari pemurnian, distilasi, demineralisasi, pelunakan, ion exchanger, dan adsorpsi. Sedangkan teknologi dalam penurunan logam $\mathrm{Fe}$ dan $\mathrm{Mn}$ terdiri dari oksidasi, Ion Exchabe, Lime Softening, Adsorption (Pengerapan), Filtration (Penyaringan). Metode filtrasi menggunakan media Pasir silika, Karbon aktif, Zeolit dan Manganese Greensand yang dibuat variasi. Hal ini dikarenakan untuk mengetahui kemampuan perbedaan kedua media dalam menurunkan $\mathrm{Fe}$ dan $\mathrm{Mn}$. Sebab fungsi pasir silika sendiri hanya sebagai filter awal dan karbon aktif sebagai adsorben. Alasan dipilihnya media zeolit yaitu harganya murah, mudah diperoleh di pasaran, dan memiliki efektifitas penyerapan $\mathrm{Fe}$ dan $\mathrm{Mn}$ yang tinggi. Sedangkan media Manganese Greensand dipilih karena mudah diperoleh di pasaran dan memiliki efektifitas penurunan $\mathrm{Fe}$ dan $\mathrm{Mn}$ yang tinggi, yaitu sebesar 93\% untuk penyerapan Besi dan Mangan (Sari Winda, 2002). Maka dari itu, dalam penelitian ini menggunakan filtrasi dengan variasi media Zeolit dan Manganese Greensand pada debit 1 L/menit, $1.5 \mathrm{~L} /$ menit, dan $2 \mathrm{~L} /$ menit, agar didapatkan efektivitas penyerapan Fe dan Mn yang lebih besar serta mengkaji perbedaan keduanya. Untuk mengatur perbedaan debit dalam penelitian ini menggunakan Hukum Darcy Weisbach (Das, Braja M., Endah, Noor, Mochtar, Indrasurya B., 1985) dengan rumus :

Keterangan :

$$
\begin{gathered}
\mathrm{Q}=\text { k.A.i.t } \\
\mathrm{k}=\frac{\text { Q.L }}{\text { h.A.I }}
\end{gathered}
$$

$\mathrm{Q}=$ Debit aliran $\left(\mathrm{cm}^{3} /\right.$ detik $)$

$\mathrm{K}=$ Koefisien permeabilitas ( $\mathrm{cm} /$ detik), tergantung dari sifat butiran

$\mathrm{i}=$ Koefisien hidrolik $=\mathrm{h} / \mathrm{L}$

$\mathrm{L} \quad=$ Ketebalan media filter $(\mathrm{cm})$

$$
\begin{aligned}
& \mathrm{h} \quad=\text { Beda tinggi antara permukaan atas } \\
& \text { bak penampung dan outlet } \\
& \text { reaktor }(\mathrm{cm}) \\
& \mathrm{A} \quad=\text { Luas penampang }\left(\mathrm{cm}^{2}\right) \\
& \mathrm{t} \quad=\text { Waktu tinggal }(\text { detik) }
\end{aligned}
$$

Hukum Darcy adalah persamaan yang mendefinisikan kemampuan suatu fluida mengalir melalui media berpori seperti batu. Hal ini bergantung pada jumlah aliran antara dua titik dengan perbedaan tekanan antara titik-titik, jarak antara titik-titik dan interkonektivitas jalur aliran antara titik-titik. Pengukuran interkonektivitas disebut permeabilitas. Dengan kata lain, hukum Darcy adalah hubungan antara debit sesaat melalui media berpori dan penurunan tekanan lebih dari jarak tertentu (Sari Lubis, 2007).

Pasir silika adalah mineral yang terdapat di kontinen bumi. Mineral ini memiliki struktur Kristal heksagonal yang terbuat dari Silika Trigonal terkristalisasi $\left(\mathrm{SiO}_{2}\right)$, dengan skala kekerasan Mohs 7 dan densitas 2.65 $\mathrm{g} / \mathrm{cm}^{3}$. Bentuk pasir silika adalah prisma segienam yang memiliki ujung piramida segienam (Holleman, A. F., dan Weiberg, N., 2001). Salah satu fungsi pasir silika adalah menyaring kekeruhan yang berasal dari kotoran, lumpur, pasir dan endapan dalam air (Purwoto, S., Purwanto, T., Hakim, L., 2015). Zeolit memiliki struktur kerangka tiga dimensi dan merupakan kristal Alumina Silica Tetrahidrat berpori, terbentuk oleh Tetrahedral $\left[\mathrm{SiO}_{4}\right]^{4-}$ dan $\left[\mathrm{AlO}_{4}\right]^{5-}$ yang saling terhubung oleh atom Oksigen, dan rongga diisi oleh logam Alkali atau Alkali tanah dan molekul air yang bergerak bebas (Chetam, 1992). Zeolit berfungsi sebagai adsorben karena strukturnya berongga dan sebagai penukar ion. Reaksi yang terjadi pada zeolit saat proses penukaran ion dengan $\mathrm{Fe}$, yaitu endapan $\mathrm{Fe}$ yang terbentuk ditukar dengan kation pada unsur logam Golongan IA dan IIA (Alkali dan Alkali Tanah) seperti $\mathrm{Na}^{+}, \mathrm{K}^{+}, \mathrm{Ca}^{2+}$, dan $\mathrm{Mg}^{2+}$ sehingga :

Zeolit. $\mathrm{Na}^{+}+\mathrm{Fe}^{3+} \longrightarrow$ Zeolit.Fe ${ }^{3+}+\mathrm{Na}^{+}$

Manganese Greensand $\left(\mathrm{K}_{2} \mathrm{Z} . \mathrm{MnO}_{2}\right.$. $\mathrm{Mn}_{2} \mathrm{O}_{7}$ ) merupakan material yang berfungsi sebagai penukar ion sehingga dapat mengoksidasi $\mathrm{Fe}$ dan $\mathrm{Mn}$ menjadi zat yang tidak larut dalam air lalu dipisahkan melalui filtrasi. Reaksi yang berlangsung yaitu :

$\mathrm{K}_{2} \mathrm{Z} \cdot \mathrm{MnO} \cdot \mathrm{Mn}_{2} \mathrm{O}_{7}+4 \mathrm{Fe}\left(\mathrm{HCO}_{3}\right) \longrightarrow 2 \mathrm{~K}_{2} \mathrm{Z}+$ $3 \mathrm{MnO}_{2}+2 \mathrm{Fe}_{2} \mathrm{O}_{3}+8 \mathrm{CO}_{2}+4 \mathrm{H}_{2}$

Selain sebagai adsorben dan penukar ion, Manganese Greensand juga berfungsi sebagai buffer (penyangga) (Said, 2003). 
Nastiti Maharani Oesman dan Sugito : Penurunan Logam Besi dan Mangan Menggunakan Filtrasi Media Zeolit dan Manganese Greensand

Karbon berpori biasa dikenal dengan nama Karbon Aktif berfungsi sebagai adsorben untuk menghilangkan warna, pengolahan limbah, dan pemurnian air. Karbon Aktif adalah arang yang telah mengalami perubahan sifat-sifat fisika dan kimianya karena dilakukan perlakuan aktifisasi dengan aktivator bahan bahan kimia ataupun dengan pemanasan pada temperatur tinggi. Karbon Aktif membentuk amorf yang sebagian besar memiliki permukaan dalam berongga, berwarna hitam, tidak berbau, tidak berasa, dan mempunyai daya serap lebih besar dibandingkan Karbon yang belum menjalani proses aktivasi (Purwoto S. dan Nugroho, W., 2013).

METODE

A. Rancangan Penelitian

Penelitian ini bersifat eksperimental yang bertujuan untuk mengetahui efektivitas penurunan konsentrasi Fe dan Mn pada air tanah dengan menggunakan Filtrasi media Pasir Silica - Zeolit - Karbon Aktif dan Pasir Silica - Manganese Greensand - Karbon Aktif. Jenis penelitian ini adalah eksperimen dimana penelitian ditempuh dengan memberikan intervensi (perlakuan) berupa filtrasi. Rancangan Penelitian ini bisa dilihat pada gambar 1.

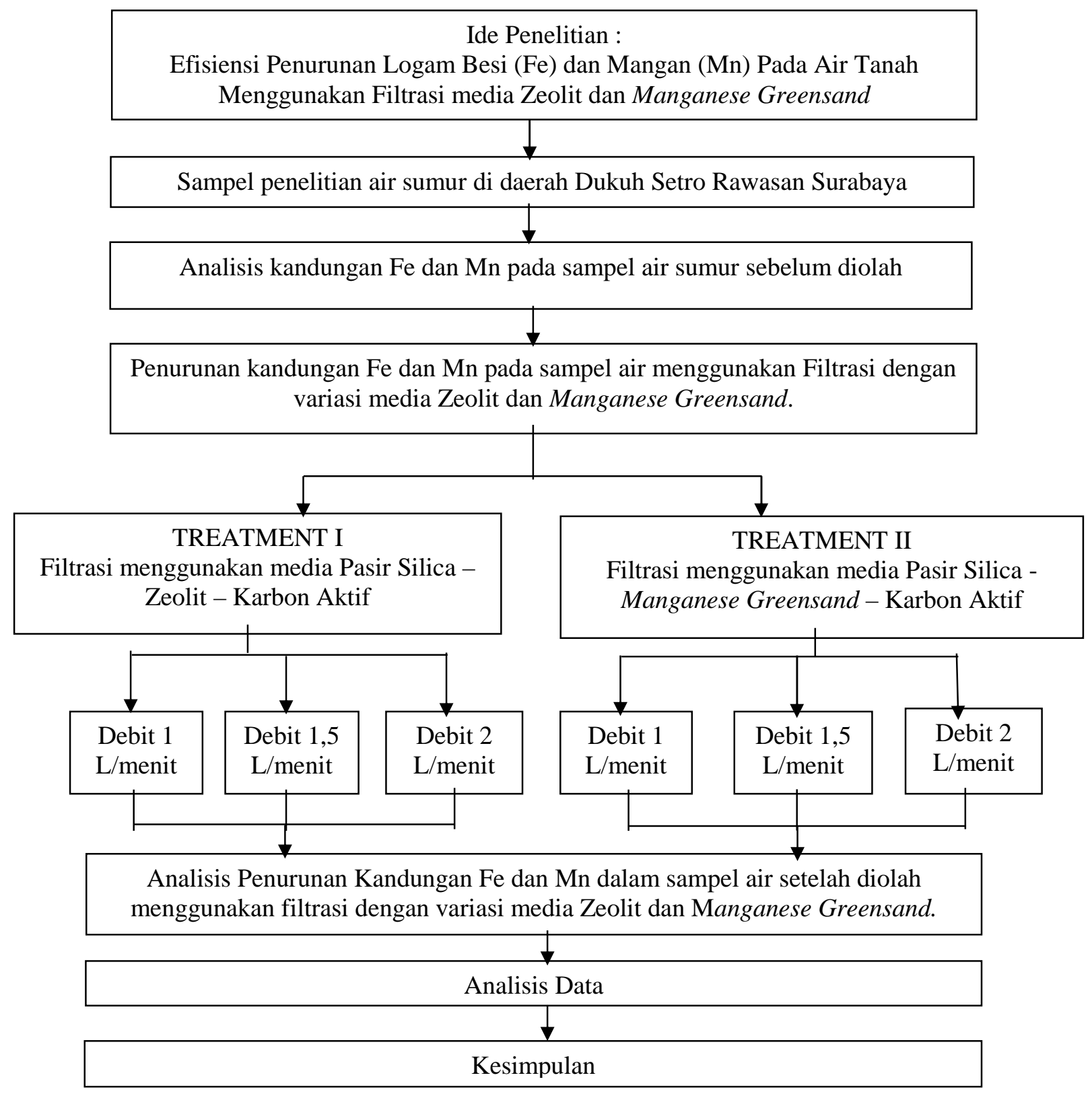

Gambar 1 Rancangan Penelitian 
Nastiti Maharani Oesman dan Sugito : Penurunan Logam Besi dan Mangan Menggunakan Filtrasi Media Zeolit dan Manganese Greensand

\section{B. Populasi dan Sampel}

1. Populasi

Populasi dalam penelitian ini adalah air tanah di Dukuh Setro Rawasan Surabaya, yang didapatkan kandungan Besi $1.4 \mathrm{mg} / \mathrm{L}$ dan Mangan $1.2 \mathrm{mg} / \mathrm{L}$.

\section{Penentuan Sampel}

Sampel penelitian ini menggunakan air sumur di Dukuh Setro Rawasan Surabaya. Sampel yang dibutuhkan selama penelitian sebanyak 30 L. Jumlah sampel ditentukan berdasarkan pemeriksaan Laboratorium yaitu $500 \mathrm{ml}$ untuk pengujian Fe dan Mn.

\section{Alat dan Bahan}

Alat dan bahan yang digunakan dalam Instalasi Filtrasi bisa dilihat pada tabel 1 .

Tabel 1 Alat dan Bahan yang digunakan dalam Pembuatan Reaktor Filtrasi

\begin{tabular}{cccc}
\hline No. & Nama Alat & Jumlah & Satuan \\
\hline 1 & Pipa PVC D 4 inchi & 2 & Buah \\
4 & Tandon air & 2 & Buah \\
5 & Pipa PVC AW 1/4 & 1 & Lonjor \\
6 & Pipa PVC AW 3/4 & 1 & Lonjor \\
7 & Pipa Fitting & 8 & Buah \\
8 & Pompa (Water pump GZ 230 IE & 1 & Buah \\
& 220 Volt kapasitas 25 L/mnt) & & \\
9 & Kayu penyangga & 4 & Buah \\
10 & Bak Penampungan & 3 & Buah \\
11 & Kasa & 6 & Buah \\
12 & Bor dan Mata Bor & 1 & Buah \\
13 & Gunting Pipa & 1 & Buah \\
14 & Kikir pipa & 1 & Buah \\
15 & Lem PVC & 1 & Buah \\
16 & Gergaji kayu & 1 & Buah \\
17 & Gelas ukur 100 ml & 1 & Buah \\
18 & Stopwatch & 1 & Buah \\
19 & Alat tulis & 1 & Buah \\
20 & Air murni & 100 & L \\
\hline
\end{tabular}

Desain Reaktor Filtrasi dapat dilihat pada gambar 2.

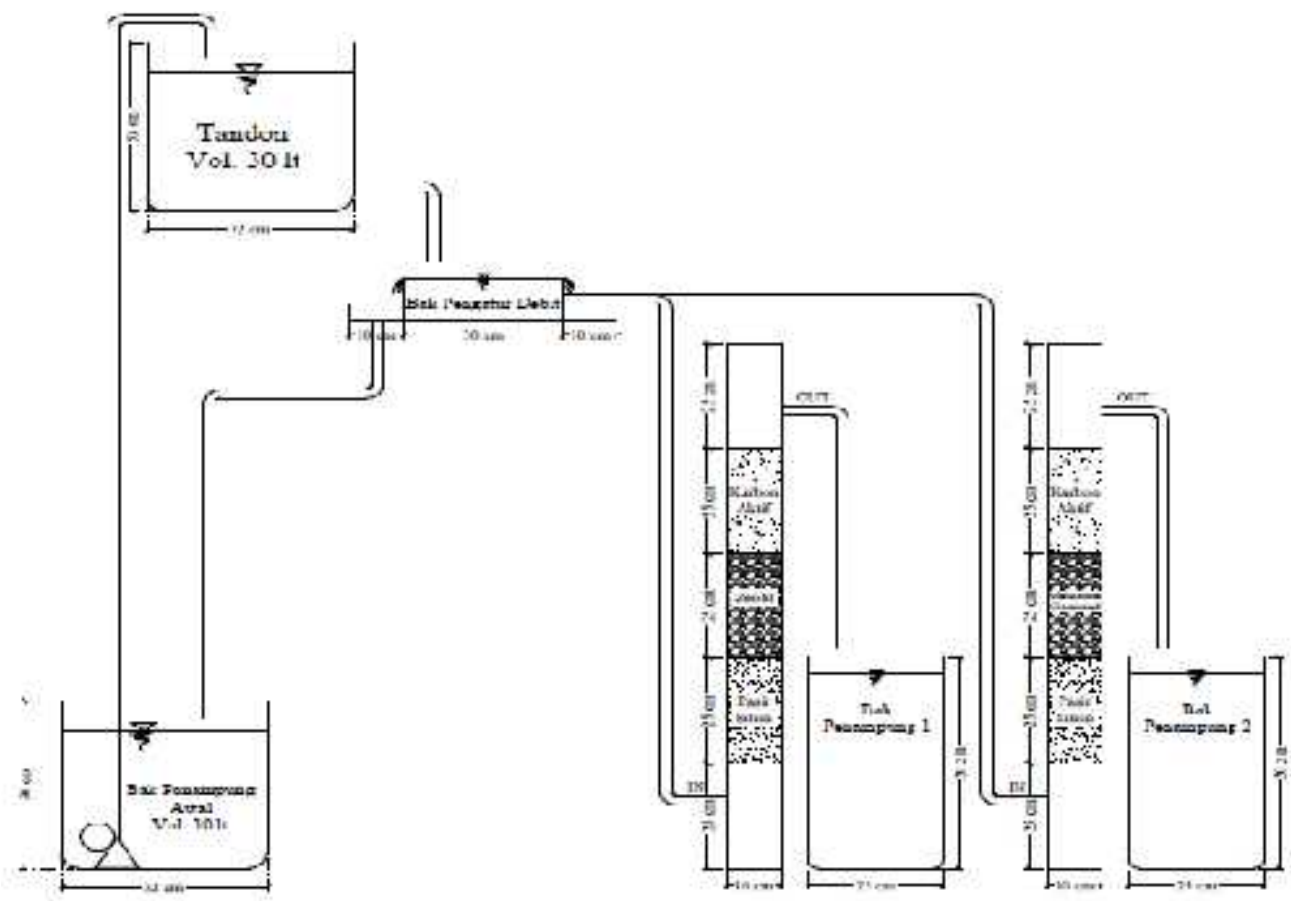

Gambar 2 Desain Reaktor Penurunan Fe dan Mn menggunakan Filtrasi 
Adapun detail tabung filter beserta medianya dapat dilihat pada gambar 3.
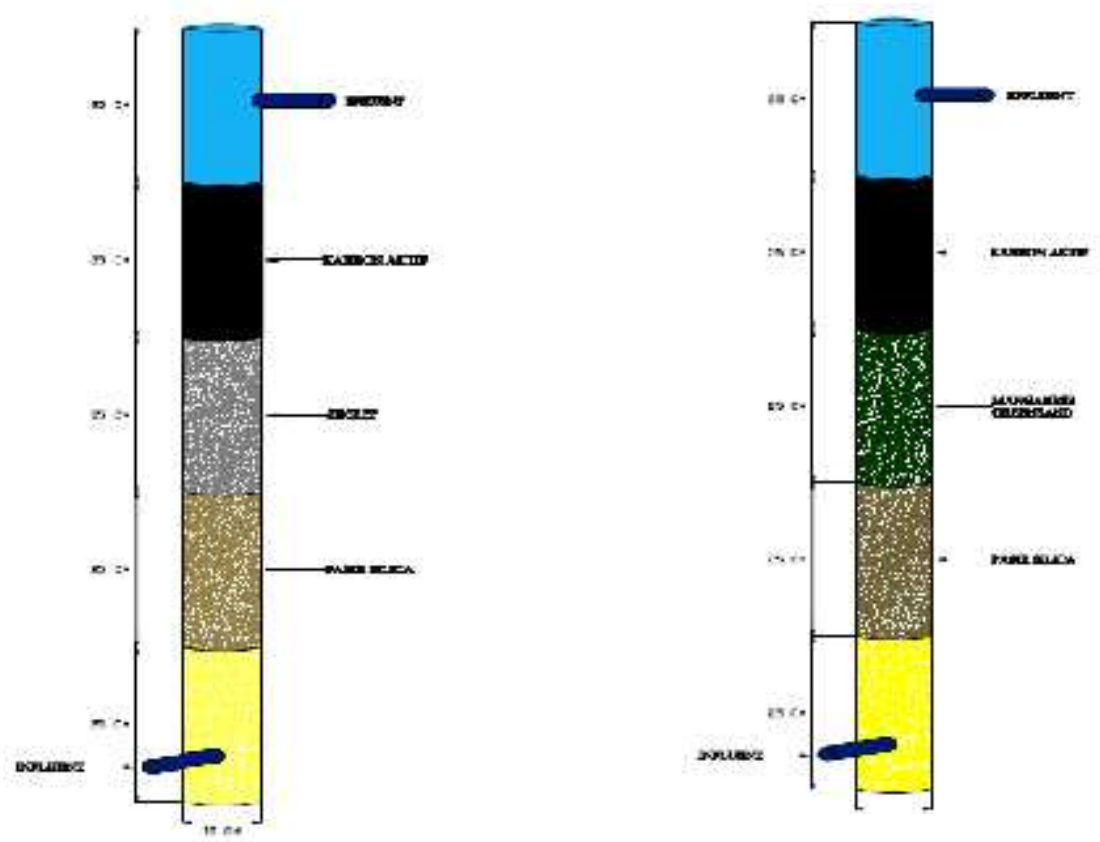

Gambar 3 Detail Tabung Filter beserta medianya

Setelah merangkai alat-alat yang digunakan dalam penelitian ini, maka tahap selanjutnya yaitu melakukan percobaan / eksperimen. Air dari bak penampung awal dipompa ke tandon atas lalu dialirkan secara gravitasi menuju masing-masing tabung filter berisi media yang berbeda dengan variasi debit. Bak pengatur debit ini diatur berdasarkan beda tinggi yang didapatkan dari Hukum Darcy Weisbach. Observasi hasil pengukuran $\mathrm{Fe}$ dan $\mathrm{Mn}$ dilakukan sebelum pengolahan dan sesudah pengolahan dengan menganalisis sampel di Laboratorium. Analisis kandungan Besi $(\mathrm{Fe})$ dalam penelitian ini menggunakan metode Ortho-Phenantrolin secara Spketrofotometri. Sedangkan analisis kandungan Mangan (Mn) dianalisa menggunakan metode Persulfat menggunakan Spektrofotometri. Analisis data dan pembahasan dilakukan berdasarkan data yang diperoleh dari hasil pengukuran parameter yang diperiksa, dalam hal ini adalah $\mathrm{Fe}$ dan Mn. Data yang diperoleh akan diolah dalam bentuk tabulasi dan disajikan dalam tabulasi dan grafik.

\section{HASIL DAN PEMBAHASAN}

\section{A. Konsentrasi Fe dan Mn setelah Treatment}

Berikut adalah konsentrasi Fe dan Mn sebelum dan sesudah treatment beserta efisiensi penurunannya menggunakan Filtrasi media Zeolit dan Manganese Greensand, seperti yang tersaji pada tabel 2 dan 3.

Tabel 2 Konsentrasi Fe dan Mn sebelum dan sesudah treatment media Pasir silika - Zeolit - Karbon Aktif

\begin{tabular}{cccccccc}
\hline No & $\begin{array}{c}\text { Debit } \\
(\mathbf{L} / \mathbf{m e n i t})\end{array}$ & $\begin{array}{c}\text { Inlet } \\
(\mathbf{m g} / \mathbf{L})\end{array}$ & $\begin{array}{c}\text { Konsentrasi Fe } \\
\text { Outlet } \\
(\mathbf{m g} / \mathbf{L})\end{array}$ & $\begin{array}{c}\text { Efisiensi } \\
(\boldsymbol{\%})\end{array}$ & $\begin{array}{c}\text { Inlet } \\
(\mathbf{m g} / \mathbf{L})\end{array}$ & $\begin{array}{c}\text { Konsentrasi Mn } \\
\text { Outlet } \\
(\mathbf{m g} / \mathbf{L})\end{array}$ & $\begin{array}{c}\text { Efisiensi } \\
(\boldsymbol{\%})\end{array}$ \\
\hline 1 & 1 & 1.6 & 0.67 & 57.13 & 1.3 & 0.39 & 70 \\
2 & 1.5 & 1.58 & 0.78 & 50.95 & 1.29 & 0.48 & 62.63 \\
3 & 2 & 1.59 & 0.87 & 45.19 & 1.29 & 0.77 & 40.46 \\
\hline
\end{tabular}


Nastiti Maharani Oesman dan Sugito : Penurunan Logam Besi dan Mangan Menggunakan Filtrasi Media Zeolit dan Manganese Greensand

Tabel 3 Konsentrasi Fe dan Mn sebelum dan sesudah treatment media Pasir silika - Manganese Greensand - Karbon Aktif

\begin{tabular}{cccccccc}
\hline No & $\begin{array}{c}\text { Debit } \\
(\mathbf{L} / \mathbf{m e n i t})\end{array}$ & $\begin{array}{c}\text { Inlet } \\
(\mathbf{m g} / \mathbf{L})\end{array}$ & $\begin{array}{c}\text { Konsentrasi Fe } \\
\text { Outlet } \\
(\mathbf{m g} / \mathbf{L})\end{array}$ & $\begin{array}{c}\text { Efisiensi } \\
(\mathbf{\%})\end{array}$ & $\begin{array}{c}\text { Inlet } \\
(\mathbf{m g} / \mathbf{L})\end{array}$ & $\begin{array}{c}\text { Konsentrasi Mn } \\
\text { Outlet } \\
(\mathbf{m g} / \mathbf{L})\end{array}$ & $\begin{array}{c}\text { Efisiensi } \\
(\boldsymbol{\%})\end{array}$ \\
\hline 1 & 1 & 1.62 & 0.35 & 78.36 & 1.3 & 0.15 & 88.21 \\
2 & 1.5 & 1.58 & 0.47 & 70.31 & 1.29 & 0.28 & 78.35 \\
3 & 2 & 1.59 & 0.65 & 59 & 1.29 & 0.45 & 65.46 \\
\hline
\end{tabular}

Tabel 2 dan 3 menunjukkan adanya efektivitas treatment. Hal ini dibuktikan dengan adanya penurunan konsentrasi $\mathrm{Fe}$ dan Mn setelah dilakukan pengolahan. Semakin kecil debit yang digunakan maka semakin besar efisiensi penurunannya, sebaliknya semakin besar debit yang digunakan maka semakin kecil efisiensi penurunannya. Penurunan terbesar terdapat pada media Pasir Silika - Zeolit - Karbon Aktif dengan debit 1 L/menit yaitu prosentase penurunannya $57,13 \%$ untuk $\mathrm{Fe}$ dan $70,00 \%$ untuk $\mathrm{Mn}$. Penurunan terbesar terdapat pada pada media Pasir Silika - Manganese Greensand Karbon Aktif dengan debit $1 \mathrm{~L} /$ menit yaitu prosentase penurunannya $78,36 \%$ untuk $\mathrm{Fe}$ dan $88,21 \%$ untuk Mn. Jika dilihat dari perbedaan kedua media, yang memberikan pengaruh lebih besar dalam menurunkan $\mathrm{Fe}$ dan Mn yaitu media Pasir Silika - Manganese Greensand - Karbon Aktif.

\section{B. Grafik Penurunan Fe dan Mn Grafik Efektivitas Removal Fe}

Berikut ini adalah grafik efektivitas removal $\mathrm{Fe}$, seperti yang tersaji pada gambar 4 .

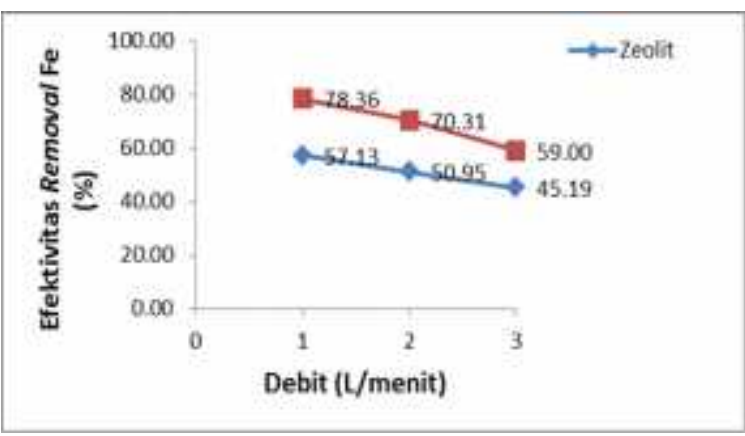

Gambar 4 Grafik Efektivitas Removal Fe

Gambar 4 menunjukkan grafik efektivitas Removal $\mathrm{Fe}$ yang dinyatakan dalam prosentase terhadap pengaruh debit. Dimana variasi debit yang diberikan dari 1 L/menit, $1.5 \mathrm{~L} /$ menit, dan $2 \mathrm{~L} /$ menit. Dapat dilihat bahwa semakin kecil debit yang mengalir, maka semakin tinggi persen efisiensinya. Begitu juga sebaliknya semakin besar debit yang mengalir, maka semakin kecil efisiensinya. Maka dari itu jika digambarkan dengan grafik terlihat menurun. Efisiensi yang paling optimum terlihat pada debit $1 \mathrm{~L} /$ menit, baik pada media Zeolit maupun Manganese Greensand. Pada media Zeolit penurunan paling optimum sebesar $57.13 \%$ yaitu pada debit $1 \mathrm{~L} / \mathrm{menit}$. Sedangkan pada media Manganese Greensand penurunan yang paling optimum juga terjadi pada debit $1 \mathrm{~L} /$ menit yaitu sebesar $78.36 \%$.

\section{b. Grafik Efektivitas Removal Mn}

Berikut ini adalah grafik efektivitas removal $\mathrm{Mn}$, seperti yang tersaji pada gambar 5 .

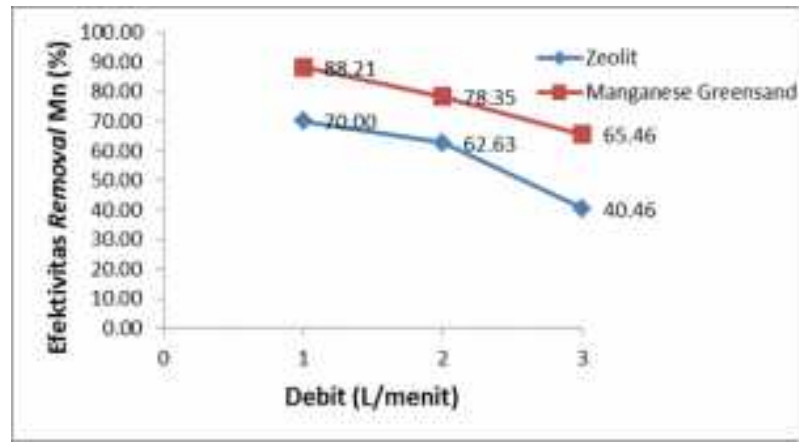

Gambar 5 Grafik Evektivitas Removal Mn

Gambar 5 merupakan grafik efektivitas removal Mn menggunakan media Zeolit dan Manganese Greensand dalam prosesntase terhadap variasi debit. Gambar 5 juga menjelaskan bahwa semakin kecil debit yang mengalir maka semakin besar efektivitas penurunannya. Debit yang paling optimum yaitu $1 \mathrm{~L} /$ menit. Pada media Zeolit, efektivitas removal Mn paling optimum sebesar $70.00 \%$ yaitu pada debit $1 \mathrm{~L} /$ menit. Gambar 5 juga menunjukkan grafik efektivitas removal $\mathrm{Mn}$ menggunakan media Manganese Greensand yang dilambangkan dengan . Efisiensi penurunan $\mathrm{Mn}$ paling optimum terjadi pada debit $1 \mathrm{~L} /$ menit yaitu sebesar $88.21 \%$. Berdasarkan grafik efektivitas removal, dapat 
Nastiti Maharani Oesman dan Sugito : Penurunan Logam Besi dan Mangan Menggunakan Filtrasi Media Zeolit dan Manganese Greensand

disimpulkan bahwa media Manganese fluktuasi. Hal ini disebabkan karena Greensand lebih efektif dalam menurunkan kadungan Fe dan Mn dalam air dibandingkan dengan media Zeolit. Hal ini disebabkan ukuran partikel media Manganese Greensand lebih kecil daripada media Zeolit.

Dari gambar 4 dan 5 dapat dilihat bahwa media Manganese Greensand lebih efektif menurunkan kandungan $\mathrm{Fe}$ dan $\mathrm{Mn}$ daripada media zeolit. Hal ini disebabkan karena ukuran partikel Manganese Greensand lebih kecil dibandingkan media zeolite. Pada penelitian ini Manganese Greensand yang digunakan memiliki diameter $0.70 \mathrm{~mm}$, sedangkan diameter zeolit adalah $1 \mathrm{~mm}$. Menurut Purwanti (2010) luas permukaan mempercepat laju reaksi karena semakin luas permukaan zat, semakin kecil ukuran partikel maka semakin banyak bagian zat yang saling bertumbukan dan semakin besar peluang adanya tumbukan, sehingga reaksi pun akan berlangsung semakin cepat. Penyebab lain media Manganese Greensand lebih efektif dalam menurunkan kandungan $\mathrm{Fe}$ dan $\mathrm{Mn}$ dibandingkan media Zeolit yaitu Zeolit yang digunakan dalam penelitian ini belum diaktivasi terlebih dahulu, namun hanya dicuci dengan aquades.

Pada gambar 4 dan 5 juga dapat dilihat bahwa baik media Zeolit maupun media Manganese Greensand lebih efektif menurunkan konsentrasi Mn dibandingkan dengan $\mathrm{Fe}$ dimana pada debit $1 \mathrm{~L} / \mathrm{menit}$. Kandungan $\mathrm{Fe}$ yang berhasil diturunkan oleh Zeolit sebesar $57.13 \%$, sedangkan kandungan Mn yang berhasil diturunkan oleh Zeolit adalah $70.00 \%$. Pada media Manganese Greensand, kandungan $\mathrm{Fe}$ yang berhasil diturunkan sebesar $78.36 \%$, sedangkan kandungan $\mathrm{Mn}$ yang berhasil diturunkan sebesar $88.21 \%$. Hal ini dapat dihubungkan dengan karakteristik dari $\mathrm{Fe}$ dan $\mathrm{Mn}$ yaitu jari-jari atom Mangan dan Besi berada dalam satu periode pada tabel periodik unsur yaitu periode 4 yang merupakan unsur-unsur transisi. Nomor atom Mn adalah 26 dan Fe adalah 27. Didalam satu periode, semakin unsur kekanan maka jari-jari atomnya semakin kecil. Sehingga dapat dikatakan bahwa ukuran logam Besi (Fe) lebih kecil dibandingkan logam Mangan (Mn) sehingga menyebabkan logam Fe yang berupa endapan dalam air akan lebih mudah lolos dan tidak tersaring oleh media. Pada penelitian ini juga menunjukkan hasil penurunan kandungan $\mathrm{Fe}$ dan Mn yang stabil dari debit $1 \mathrm{~L} /$ menit, 1.5 L/menit, sampai $2 \mathrm{~L} /$ menit dan tidak terjadi pengaturan debit dari perbedaan tinggi muka air sehingga dihasilkan aliran up flow yang stabil.

Penelitian ini lebih efektif jika dibandingkan dengan penelitian yang dilakukan oleh Anika (2012) menggunakan aerated filter dengan media Zeolit berhasil mereduksi Besi sebesar 62.31\%. Hal ini dikarenakan pada penelitian sebelumnya zeolit hanya disusun pada reaktor aerasi sehingga Zeolit sendiri tidak berfungsi secara optimal sebagai media filter. Sedangkan penelitian yang dilakukan oleh Rhidatul Akbar (2014) menunjukkan hasil penelitian yang lebih efektif dibandingkan penelitian ini, yaitu menggunakan media yang sama berupa Pasir Silika, Zeolit, dan Karbon Aktif dengan waktu tinggal 5 menit berhasil menurunkan kandungan $\mathrm{Fe}$ sebesar 96.17\%. Hal ini dikarenakan pada penelitian ini waktu tinggal paling optimum hanya sebesar 4.8 menit, sehingga menyebabkan penelitian ini kurang efektif dibandingkan penelitian sebelumnya.

Hasil penelitian ini juga kurang efektif dibandingkan penelitian sebelumnya Rahmawati dan Sugito (2015) menggunakan media filtrasi Zeolit dan Manganese Greensand terpadukan resin menghasilkan efektivitas removal $\mathrm{Fe}$ sebesar $94 \%$ dan $\mathrm{Mn}$ sebesar $99 \%$. Hal ini dikarenakan karena teknologi yang dilakukan pada penelitian sebelumnya merupakan teknologi kombinasi dari filtrasi dan resin penukar ion. Tetapi pada penelitian sebelumnya membutuhkan biaya yang mahal sebab menggunakan teknologi kombinasi, sedangkan pada penelitian ini biaya yang digunakan relatif murah. Jika konsentrasi Fe dan Mn tidak terlalu besar, maka cukup menggunkan teknologi filtrasi seperti pada penelitian ini. Penelitian ini mampu menurunkan kandungan $\mathrm{Fe}$ dan $\mathrm{Mn}$ hingga dibawah nilai baku mutu Air Bersih sesuai PERMENKES 416/1990 yaitu Fe sebesar $1 \mathrm{mg} / \mathrm{L}$ dan $\mathrm{Mn}$ sebesar $0.5 \mathrm{mg} / \mathrm{L}$.

\section{KESIMPULAN}

Kesimpulan dalam penelitian ini adalah adanya penurunan kandungan $\mathrm{Fe}$ dan $\mathrm{Mn}$ menggunakan filtrasi media Pasir Silika Zeolit - Karbon Aktif dan Pasir Silika Manganese Greensand - Karbon Aktif. Efektivitas penurunan kandungan $\mathrm{Fe}$ menggunakan media Zeolit sebesar 57.13\% dan Mn sebesar 70.00\%. Sedangkan efektivitas penurunan kandungan $\mathrm{Fe}$ menggunakan media manganese greensand 
Nastiti Maharani Oesman dan Sugito : Penurunan Logam Besi dan Mangan Menggunakan Filtrasi Media Zeolit dan Manganese Greensand

sebesar $78.36 \%$ dan Mn sebesar $88.21 \%$.

Debit yang paling optimal untuk menurunkan

kandungan Fe dan Mn menggunakan media

Zeolit dan Manganese Greensand dalam penelitian ini yaitu debit $1 \mathrm{~L} / m e n i t$. Hal ini dikarenakan semakin kecil debit, semakin lama waktu tinggal, maka semakin besar efektivitas penurunannya.

\begin{abstract}
Ucapan Terima Kasih
Ucapan terima kasih disampaikan kepada suami yang telah membantu menyelesaikan penelitian ini dan kepada seluruh staf pengajar Program Studi Teknik Lingkungan Universitas PGRI Adi Buana Surabaya yang telah mendukung dan memberikan pengarahan demi terselesainya penelitian ini.
\end{abstract}

\section{DAFTAR PUSTAKA}

Akbar Rhidatul. 2014. Keefektifan Waktu Tinggal Pada Proses Filtrasi Dalam Menurunkan Kadar Besi (Fe) Air Sumur di Perum Griya Fajar Gentan Baki Sukoharjo.Surakarta : Program Studi S1 Kesehatan Masyarakat, Fakultas Ilmu Kesehatan, Universitas Muhammadiyah Surakarta.

Anika. 2012. Pengaruh Jenis Media Pada AeratedFilter Terhadap Penurunan Kadar Besi Dan Mangan Air Sumur Gali. Surabaya :Program Studi S-1 Ilmu dan Teknologi Lingkungan, Departemen Biologi Fakultas Sains dan Teknologi, Universitas Airlangga.

Cheetam, D., A. 1992 dalam Rahmawati, N. dan Sugito.(2015). Reduksi Besi (Fe) dan Mangan (Mn) pada Air Tanah Menggunakan Media Filtrasi Manganese Greensand dan Zeolit Terpadukan Resin. Jurnal Teknik WAKTU; Volume 13; Nomor: 02; Juli 2015; Hal.63-71.

Das, Braja M., Endah, Noor, Mochtar, Indrasurya B., Mekanika Tanah (Prinsi-prinsip Rekayasa Geoteknis) Jilid 1, 1985, Erlangga, Jakarta.

Holleman, A. F., dan Weiberg, N., 2001. Inorganic Chemistry, Academic Press, San Diego.

Maulana, Fivry W. 2014. Hubungan Air Tanah dan Kondisi Geologi dalam Penentuan Kualitas dan Potensi Air Tanah Kecamatan Bruno Kabupaten Purworejo Propinsi Jawa Tengah. Yogyakarta: Mahasiswa Magister Teknik Geologi UPN “Veteran” Yogyakarta

Purwanti. 2010. Laju Reaksi. Yogyakarta : Universitas Negeri Yogyakarta.

Purwoto, S. dan Nugroho, W., 2013. Removal Klorida, TDS, Dan Besi Pada Air Payau Melalui Penukar Ion Dan Filtrasi Campuran Zeolit dengan Karbon Aktif.Jurnal Teknik WAKTU; Volume 11; Nomor: 01; Januari 2013.

Purwoto, S., Purwanto, T., Hakim, L., 2015. Penjernihan Air Sungai Dengan Perlakuan Koagulasi,Filtrasi, Absorbsi dan Pertukaran Ion Jurnal Teknik WAKTU; Volume 13; Nomor: 02; Juli 2015.

Rahmawati, N. dan Sugito.(2015). Reduksi Besi (Fe) dan Mangan (Mn) pada Air Tanah Menggunakan Media Filtrasi Manganese Greensand dan Zeolit Terpadukan Resin. Jurnal Teknik WAKTU; Volume 13; Nomor: 02; Juli 2015; Hal.63-71.

Said, N. I. 2003. Metoda Praktis Penghilangan Zat Besi dan Mangan di Dalam Air Minum.Jakarta : Kelair BPPT. 2003.

Said, N.I. 2005. Metode Penghilangan Zat Besi dan Mangan di dalam Penyediaan Air Minum Domestik.Jurnal Air Indonesia (JAI), 1(5) 239 - 250.

Said, N.I. 2005. Metoda Penghilangan Zat Besi dan Mangan di dalam Penyediaan Air Minum Domestik.Jurnal Teknologi Volume 1 Nomor 3 BPPT.

Sari, Lubis. 2007. Keterhantaran Hidraulik dan Permeabilitas. Fakultas Pertanian Universitas Sumatera Utara : Sumatera Utara.

Sari, Winda K., dan Karnaningroem, N. 2002. Penurunan Besi dan Mangan dengan menggunakan cascade Aerator dan Rapid Sand Filter pada Air Sumur Gali. Surabaya: Fakultas Teknik Lingkungan, Fakultas FTSP Kampus ITS Sukolilo Surabaya. 